\title{
Effect of magnetic field and silver nanoparticles on yield and water use efficiency of Carum copticum under water stress conditions
}

\author{
Mohammadjavad Seghatoleslami ${ }^{1 *}$, Hassan Feizi ${ }^{2}$, Gholamreza Mousavi ${ }^{3}$, Aliasghar Berahmand ${ }^{4}$ \\ ${ }^{1}$ Islamic Azad University, Birjand branch, Birjand, Iran \\ ${ }^{2}$ University of Torbat-e-Heydarieh, Torbat-e-Heydarieh, Iran \\ ${ }^{3}$ Islamic Azad University, Birjand branch, Birjand, Iran \\ ${ }^{4}$ Mashhad, Iran \\ "Corresponding author: e-mail: mjseghat@yahoo.com
}

\begin{abstract}
Normally the productivity of cropping systems in arid and semi- arid regions is very low. The sustainable agricultural systems try to find out environmental friendly technologies based on physical and biological treatments to increase crop production. In this study two irrigation treatments (control and water stress) and six methods of fertilizer treatment (control, NPK-F, using magnetic band- $\mathrm{M}$, using silver nano particles- $\mathrm{N}, \mathrm{M}+\mathrm{N}$ and $\mathrm{M}+\mathrm{N}+50 \% \mathrm{~F}$ ) on performance of ajowan were compared. Results showed that treatments with magnetic field or base fertilizer had more yield compared to the control and silver nanoparticles $(\mathrm{N})$ treatments. Application of silver nanoparticles had no positive effect on yield. The highest seed and biomass WUE achieved in base fertilizer or magnetic field treatments. Under water stress treatment, seed WUE significantly increased. In conclusion magnetic field exposure, probably by encourage nutrient uptake efficiency could be applied to reduce fertilizer requirement. On the other hand the cultivation of plants under low MF could be an alternative way of WUE improving.
\end{abstract}

Keywords: biomass, harvest index, yield components.

\section{INTRODUCTION}

Drought stress is one of the most important significant stresses affecting agricultural productivity ${ }^{1,2}$. One way for adapting to conditions of drought would be choose locally adapted plants ${ }^{3}$. Carum copticum is a locally adapted medicinal plant suitable for the climate of Birjand, Iran. When new species are introduced, local farmers want to know whether or not they demand less water and how water deficit will affect a final yield ${ }^{3}$. Some research has been done to evaluate growth and yield of medicinal plants in conditions of water stress.

The result of Khalid ${ }^{4}$ showed that fresh and dry weight of Ocimum sp. significantly reduced in water stress conditions. Ahmadian et al. ${ }^{5}$, in an experiment on chamomile indicated that the control treatment of irrigation (90\% FC) had the highest flower and biomass yields. Farahza et al. $^{6}$ in an experiment on cumin observed that FC treatment recorded the highest seed yield, 1000 seed weight, number of umbels per plant and biological yield. Ucan et al. ${ }^{7}$ found no difference in the yield of sesame (Sesamum indicum L.) using irrigation intervals of 7, 14 and 21 days.

In arid and semi- arid regions one of the greatest challenges for agriculture is to develop technology or agronomic options to improve water use efficiency ${ }^{8}$. In these regions, it is in farmers' best interests to find out whether or not a longer irrigation interval would provide an acceptable level of local crop production and high WUE'. Plants decrease evapotranspiration by blocking stomata and reducing leaf area, plant height and branching. Therefore, WUE of medicinal and aromatic plants increases under drought stress conditions ${ }^{10}$. Egilla et al. ${ }^{11}$ indicated that WUE of Hibiscus rosa- sinensis increased under drought stress.

Productivity of cropping systems in arid and semi- arid regions is normally very low due to a combination of low and unpredictable water supply and low soil nutrient concentrations ${ }^{12}$. An intensive farming practice that warrants high yield and quality requires extensive use of chemical fertilizers ${ }^{13}$. Large quantities of chemical fertilizers are used to replenish $\mathrm{N}$ and $\mathrm{P}$ in soil, which is costly and contributes of severe environmental contamination ${ }^{13}$ for example nitrate leaching ${ }^{14}$.

Sustainable agricultural systems rely on environmentally friendly technologies based on physical and biological treatments to increase crop production ${ }^{15}$. Magnetic fields reportedly exert a positive effect on plant growth and development ${ }^{16}$.

Aldjadjiyan ${ }^{17}$ demonstrated the effect of the magnetic field of $0.15 \mathrm{~T}$ in strength on maize samples that led to an increase of shoot fresh weight and length. Martinez et al. ${ }^{18}$ demonstrated that germination rate and first growth stages of tomato seedlings increased when tomato seeds were exposed to a magnetic field. Also, in an experiment magnetic field stimulated the rooting process in plant material from oregano ${ }^{19}$.

Magnetic field (MF) may play an important role in cation uptake capacity and has a positive effect on immobile plant nutrient uptake ${ }^{20}$. The positive effects of MF are apparent on plants' photochemical activity, respiration rate, protein biosynthesis, cell division, enzyme activities, nucleic acid content and growth- development period ${ }^{\mathbf{2 1}, 22}$. This positive effect of magnetic field treatment may be due to paramagnetic properties of some atoms in plant cells and pigments such as chloroplasts ${ }^{23}$.

Nanotechnology offers an important role in improving existing crop management techniques ${ }^{24}$. Nanotechnology has the potential to revolutionize the agricultural and food industries ${ }^{25}$. Applying nanomaterials to improve soil fertility and water retention links soil science and agriculture to surface chemistry ${ }^{26}$. In research experiments one of the most commonly used nano particles is that of silver. Some research has demonstrated the inhibitory effect of silver nano particles on bacteria and microorganisms ${ }^{27,28}$. Research has reported positive effects of $\mathrm{Ag}^{+}$on plant stem hydraulic conductivity ${ }^{29}$, but it has also been reported that these nano particles 
could penetrate a plant system and may interfere with intracellular components, and cause damage to cell division ${ }^{30}$. Stampoulis et al. ${ }^{31}$ showed that a decrease in Zucchini plant biomass and transpiration was observed on prolonging their growth in presence of $\mathrm{Ag}^{+}$NPs. Musante and White ${ }^{32}$ stated $\mathrm{Ag}$ nano particles reduced biomass and transpiration of Cucurbita pepo.

Not only is there a growing interest in using physical based materials in agriculture, there is also little information on medicinal plant responses to such material, especially in drought stress conditions. This experiment was done to evaluate responses of Carum copticum to drought stress under treatments testing silver nano particles and a magnetic field.

\section{MATERIAL AND METHODS}

This experiment was done in the growing season of 2010 at the Agricultural Research Center of Islamic Azad University, Birjand branch, Iran. Longitude, latitude and altitude of Birjand are $59^{\circ} 13^{\prime}, 32^{\circ} 53^{\prime}$ and $1480 \mathrm{~m}$, respectively. Birjand has a dry and warm climate and rainfall mainly occurs between the months of November to April. Annual average rainfall is $167 \mathrm{~mm}$. Total precipitation in the year of the experiment was 161.8 $\mathrm{mm}$. Electrical conductivity (EC) of the irrigation water was $2.6 \mathrm{ds} \cdot \mathrm{m}^{-1}$. Soil texture and $\mathrm{pH}$ were sandy and 8.2 , respectively. Nitrogen, phosphorus and potassium content in the soil were $0.033 \%, 6.8 \mathrm{ppm}$ and $133 \mathrm{ppm}$, respectively.

A split- plot experiment was used based on a randomized complete block design with three replications. Two irrigation treatments (control- once a week until the end of growth and water stress- once a week until the start of flowering and after that every other week until the end of growth) were as main plots and six soil fertilizing methods (control without fertilizer, fertilizing with $\mathrm{N}-\mathrm{P}-\mathrm{K}$ based on soil analysis- $\mathrm{F}$, using magnetic band- $\mathrm{M}$, using silver nano particles- $\mathrm{N}, \mathrm{M}+\mathrm{N}$ and $\mathrm{M}+\mathrm{N}+50 \% \mathrm{~F}$ ) were as sub plots.

Each sub plot had three ridges. The lengths of ridges and distances between them were 4 and $0.8 \mathrm{~m}$, respectively. Sowing was done on both sides of the ridges on $14^{\text {th }}$ March. The distance between plants after thinning was $15 \mathrm{~cm}$.

The base fertilizer for $\mathrm{F}$ treatment consisted 300 $\mathrm{kg} \cdot \mathrm{ha}^{-1}$ urea, $150 \mathrm{~kg} \cdot \mathrm{ha}^{-1}$ potassium sulfate and 100 $\mathrm{kg} \cdot \mathrm{ha}^{-1}$ triple super phosphate. Urea was used at two stages $(50 \%$ at the start of stem elongation and $50 \%$ at the start of flowering). Two other fertilizers were used before planting. In $\mathrm{M}$ treatment, $3 \times 1 \mathrm{~cm}$ pieces of magnetic bands (10 MT) were placed under sowing rows before seeding. In $\mathrm{N}$ treatment, $40 \mathrm{~g} \cdot \mathrm{ha}^{-1}$ colloidal nano silver in the irrigation water was applied after thinning. Figure 1 shows a size of the silver nano particles, taken with a Transition Electron Microscope (TEM).

Weed control was done as hand weeding and when required. Biomass and seed yield were determined from the harvest of $2 \mathrm{~m}^{2}$ on $10^{\text {th }}$ September, with due regard to border effects. Harvest index (HI) and water use efficiency (WUE) for biomass and seed were also determined through seed yield/biomass yield and yield/ irrigation volumes, respectively. Umbel and seed number

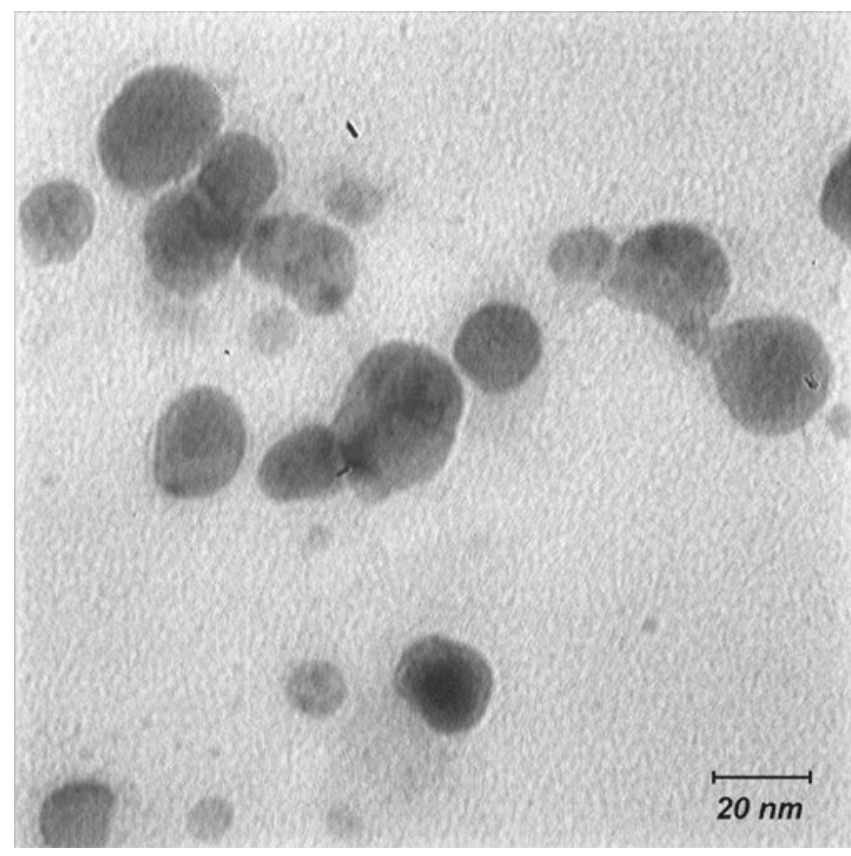

Figure 1. Image of silver nano particles size by Transition Electron Microscope (TEM)

per plant were measured randomly in 10 plants from each sub plot.

Data analysis was done by MSTAT-C software and means were compared by Duncan's multiple range tests at $5 \%$ probability level.

\section{RESULTS AND DISCUSSION}

The effect of irrigation on seed and biomass yield was not significant. Although drought stress increased seed yield from 119.7 to $142.5 \mathrm{~g} \cdot \mathrm{m}^{-1}$, this increase was not significant (Table 1). Carum copticum is an indeterminate plant and produces flowers over a long period of time. It can be said that every other week irrigation in the reproductive development stage caused a reduction in competition between vegetative and reproductive organs of plants. Actually Carum copticum is probably a sink limited plant, because when assimilate production is limited through drought stress, seed yield was not affected.

Drought stress declined biomass yield $(26.9 \%)$ but this reduction was not significant (Table 1). Drought stress severity was not high enough to significantly reduce plant growth.

Khazaie et al. ${ }^{9}$ indicated that irrigation intervals did not change biomass of thyme (Thymus vulgaris) and hyssop (Hyssopus officinalis). Research by Ucan et al. ${ }^{7}$ found no difference in the yield of sesame (Sesamum indicum) using irrigation intervals of 7, 14 and 21 days. Bannayan et al. $^{3}$ in an experiment over two years on Nigella sativa, it was indicated that in the first year of the experiment, irrigation termination at the seed formation stage declined straw yield significantly, but it had no significant effect on seed yield.

Seed yield components are shown in (Table 1). Table 4 shows that seed and umbels number per plant reduced in drought stress treatment about 21 and 5\% respectively, but this reduction was not significant. 1000 seed weight increased significantly in drought stress conditions (Table 1). Bannayan et al. ${ }^{3}$ showed that although termination of irrigation at the blooming stage had the lowest 
Table 1. Effect of irrigation on yield and yield components of Carum copticum

\begin{tabular}{|l|c|c|c|c|c|}
\hline Treatments & $\begin{array}{c}\text { Seed yield } \\
{\left[\mathrm{g} \cdot \mathrm{m}^{-2}\right]}\end{array}$ & $\begin{array}{c}\text { Biomass yield } \\
{\left[\mathrm{g} \cdot \mathrm{m}^{-2}\right]}\end{array}$ & Seed number per plant & Umbel number per plant & 1000 seed weight $[\mathrm{g}]$ \\
\hline Deficit irrigation & $142.52 \mathrm{a}$ & $263.62 \mathrm{a}$ & $8025.2 \mathrm{a}$ & $112.0 \mathrm{a}$ & $1.077 \mathrm{a}$ \\
\hline Control & $119.73 \mathrm{a}$ & $360.67 \mathrm{a}$ & $8312.2 \mathrm{a}$ & $141.6 \mathrm{a}$ & $0.882 \mathrm{~b}$ \\
\hline
\end{tabular}

Means followed by the same letter within each column are not significantly different according to Duncan multiple test $(P=0.05)$

Table 2. Effect of fertilizer, magnetic field and silver nano particles on yield and yield components of Carum copticum

\begin{tabular}{|l|c|c|c|c|c|}
\hline Treatments & $\begin{array}{c}\text { Seed yield } \\
{\left[\mathrm{g} \cdot \mathrm{m}^{-2}\right]}\end{array}$ & $\begin{array}{c}\text { Biomass yield } \\
{\left[\mathrm{g} \cdot \mathrm{m}^{-2}\right]}\end{array}$ & Seed number per plant & Umbel number per plant & 1000 seed weight [g] \\
\hline Control & $98.03 \mathrm{~b}$ & $237.38 \mathrm{~b}$ & $6573.6 \mathrm{c}$ & $96.1 \mathrm{~b}$ & $0.920 \mathrm{ab}$ \\
\hline $\mathrm{B}$ & $141.40 \mathrm{a}$ & $345.40 \mathrm{a}$ & $7551.1 \mathrm{bc}$ & $154.8 \mathrm{a}$ & $1.147 \mathrm{a}$ \\
\hline $\mathrm{M}$ & $137.59 \mathrm{a}$ & $327.51 \mathrm{a}$ & $8361.8 \mathrm{abc}$ & $126.7 \mathrm{ab}$ & $0.993 \mathrm{ab}$ \\
\hline $\mathrm{N}$ & $97.51 \mathrm{~b}$ & $251.39 \mathrm{~b}$ & $6578.2 \mathrm{c}$ & $102.0 \mathrm{~b}$ & $0.880 \mathrm{~b}$ \\
\hline $\mathrm{M}+\mathrm{N}$ & $161.68 \mathrm{a}$ & $355.45 \mathrm{a}$ & $10751.4 \mathrm{a}$ & $146.6 \mathrm{a}$ & $0.923 \mathrm{ab}$ \\
\hline $\mathrm{M}+\mathrm{N}+50 \% \mathrm{~B}$ & $150.54 \mathrm{a}$ & $355.72 \mathrm{a}$ & $9159.9 \mathrm{ab}$ & $134.5 \mathrm{ab}$ & $1.014 \mathrm{ab}$ \\
\hline
\end{tabular}

$\mathrm{B}:$ Base fertilizer - M: Magnetic field $-\mathrm{N}$ : silver nano particles.

number of follicles per plant for black cumin and spike number per plant for isabgol, 1000 seed weight was not significantly affected. Other research, Ahmadian et al. ${ }^{33}$ on cumin demonstrated that irrigation time had a positive effect on number of seeds and number of umbels per plant, but had a negative effect on 1000 seed weight.

Weekly irrigation caused high competition between vegetative organs and filling seeds. It is noteworthy that every other week irrigation at the reproductive stage was the most favorable for seed filling.

The effect of fertilizer treatments on seed and biomass yields was significant. Treatments with magnetic field or base fertilizer (B, M, M+N and $\mathrm{M}+\mathrm{N}+50 \%$ B) had higher yields compared to the control and nano silver (N) treatments (Table 2). De Souza et al. ${ }^{34}$ in an experiment on tomato seedlings showed that magnetic treatment stimulated dry matter production and improved its partitioning. The research asserted that magnetic field induced an improvement in plants' capacity for nutrient and water uptakes. Research by Rochalska et $a l .{ }^{35}$ on sugar beet indicated that a magnetic field increased leaf chlorophyll content and growth of root mass during the growing period that resulting in higher yields.

Magnetic field may play an important role in plant cation uptake capacity as well as having a positive effect on immobile plant nutrient ${ }^{20}$. In an experiment on date palm, Dhawi et al. ${ }^{36}$ indicated that plants' element composition was significantly affected by the intensity of a static magnetic field.

Silver nano particle application had no positive effect on yield (Table 2). Stampoulis et al. ${ }^{31}$ reported a decrease in plant biomass and transpiration in the presence of silver nano particles. Kumari et al ${ }^{30}$ in Allium cepa showed that Ag NPs impaired the stage of cell division and caused cell disintegration. It has been reported that treatment with silver nano particles inhibits microbial growth $^{28,37}$. In that case the most probable positive effects of silver nano particles could be observed in conditions that are disinfected, for example when planting in soil infected soil with microbia.

Seed number per plant was significantly affected by fertilizing treatments. The highest seed number per plant was recorded from $\mathrm{M}+\mathrm{N}$ treatment, but it was not significantly different from $\mathrm{M}$ and $\mathrm{M}+\mathrm{N}+50 \%$ B treatments (Table 2). Faqenabi et al. ${ }^{38}$ in an experiment on safflower showed that magnetic field treatment increased number of seeds per head. Similar to yield, treatments with magnetic field or base fertilizer $(\mathrm{B}, \mathrm{M}, \mathrm{M}+\mathrm{N}$ and $\mathrm{M}+\mathrm{N}+50 \% \mathrm{~B}$ ) had more umbels per plant and higher records of 1000 seed weight (Table 2). Drought stress significantly increased $\mathrm{HI}$ from 0.339 to 0.539 (Table 3).

Table 3. Effect of irrigation on HI and WUE of Carum copticum

\begin{tabular}{|l|c|c|c|}
\hline Treatments & $\mathrm{HI}$ & $\begin{array}{c}\text { Seed WUE } \\
{\left[\mathrm{g} \cdot \mathrm{I}^{-1}\right]}\end{array}$ & $\begin{array}{c}\text { Biomass } \\
\text { WUE }\left[\mathrm{g} \cdot \mathrm{I}^{-1}\right]\end{array}$ \\
\hline Deficit irrigation & $0.539 \mathrm{a}$ & $0.228 \mathrm{a}$ & $0.422 \mathrm{a}$ \\
\hline Control & $0.339 \mathrm{~b}$ & $0.133 \mathrm{~b}$ & $0.402 \mathrm{a}$ \\
\hline
\end{tabular}

Means followed by the same letter within each column are not

significantly different according to Duncan multiple test $(P=0.05)$

This means that vegetative organs were more affected by drought than reproductive ones. As previously mentioned, Carum copticum is an indeterminate plant that produces new branches and umbels simultaneously after the beginning of the reproductive stage. In drought stress treatment, when irrigation was limited at the reproductive stage, plants allocated limited water and assimilates to produce umbels and seeds, but in the control treatment, assimilates were partitioned between umbels and new branches. These results are the opposite of those determined by Earl and Davis ${ }^{39}$, which concluded that HI declined when a brief period of stress coincided with the critical developmental stage around the flowering period in maize. The reason for this different result is that maize is a determinate plant that produces flowers and seeds in a short period of time. Furthermore, results of Amini Dahaghi and Mollafilabi ${ }^{\mathbf{4 0}}$ in cumin, also an indeterminate plant, indicated that increasing irrigation times significantly decreased HI.

The effect of fertilizer treatments on HI was not significant (Table 4), thus vegetative and reproductive organs of plants were similarly affected by these treatments.

According to the proposal that magnetic field probably increases cation uptake capacity and immobile plant nu-

Table 4. Effect of fertilizer, magnetic field and silver nano particles on HI and WUE of Carum copticum

\begin{tabular}{|l|c|c|c|}
\hline Treatments & HI & $\begin{array}{c}\text { Seed WUE } \\
{\left[\mathrm{g} \cdot \mathrm{I}^{-1}\right]}\end{array}$ & Biomass WUE $\left[\mathrm{g} \cdot \mathrm{I}^{-1}\right]$ \\
\hline Control & $0.427 \mathrm{a}$ & $0.134 \mathrm{~b}$ & $0.314 \mathrm{~b}$ \\
\hline $\mathrm{B}$ & $0.430 \mathrm{a}$ & $0.196 \mathrm{a}$ & $0.454 \mathrm{a}$ \\
\hline $\mathrm{M}$ & $0.434 \mathrm{a}$ & $0.193 \mathrm{a}$ & $0.439 \mathrm{a}$ \\
\hline $\mathrm{N}$ & $0.413 \mathrm{a}$ & $0.134 \mathrm{~b}$ & $0.326 \mathrm{~b}$ \\
\hline $\mathrm{M}+\mathrm{N}$ & $0.469 \mathrm{a}$ & $0.223 \mathrm{a}$ & $0.474 \mathrm{a}$ \\
\hline $\mathrm{M}+\mathrm{N}+50 \% \mathrm{~B}$ & $0.459 \mathrm{a}$ & $0.206 \mathrm{a}$ & $0.465 \mathrm{a}$ \\
\hline
\end{tabular}

$\mathrm{B}$ : Base fertilizer $-\mathrm{M}$ : Magnetic field $-\mathrm{N}$ : silver nano particles. 
trients uptake $\mathrm{e}^{\mathbf{2 0}}$, it should therefore enhance all growth parameters dependent on photosynthesis.

Seed WUE was significantly affected by irrigation and levels increased in drought stress conditions, but biomass WUE was not affected (Table 3). Different responses of seed and biomass WUE to drought stress treatment are demonstrated by HI responses to this treatment. Increasing WUE under drought stress has been reported by Cheruth et al. ${ }^{41}$ in Catharanthus roseus and Faraji et al. $^{42}$ in canola.

The effect of fertilizer treatment on seed and biomass WUE was significant (Table 4). Considering the formula of WUE, when irrigation volume is equal to fertilizer treatment, trends for seed and biomass WUE were similar to seed and biomass yields. Thus the highest seed and biomass WUE (Table 4) related to treatments with base fertilizer or magnetic field $(\mathrm{B}, \mathrm{M}, \mathrm{M}+\mathrm{N}$ and $\mathrm{M}+\mathrm{N}+50 \% \mathrm{~B})$.

In conclusion, although magnetic field exposure could increase plant growth and yield; using silver nano particles had no positive effect on plant growth. Considering the disinfectant capacity of silver nano particles, its application may be useful in soil with microbial contamination. Magnetic field exposure, probably through increasing nutrients uptake efficiency, could be used to reduce fertilizer requirement, which is particularly important in medicinal plant production and organic farming. However, considering that methods for more efficient irrigation scheduling are needed for commercial farmers, cultivation under low MF could be an alternative way to improve WUE within the framework of future agricultural techniques. However, more extensive research experiments are needed concerning plant growth when exposed to various nano particles or a magnetic field.

\section{LITERATURE CITED}

1. Ludlow, M.M. \& Muchow, R.C. (1990). A critical evaluations of traits for improving crop yields in water- limited environments. Adv. Agron. 43, 107-153.

2. Razmjoo, K., Heydarizadeh, P. \& Sabzalian, M.R. (2008). Effect of salinity and drought stress on growth parameters and essential oil content of Matricaria chamomile. Int. J. Agric. Biol. 10, 451-454. http://www.fspublishers.org, 07-063/ ASB/2008/10-4-451-454.

3. Bannayan, M., Nadjafi, F., Azizi, M., Tabrizi, L. \& Rastgoo, M. (2008). Yield and seed quality of Plantago ovata and Nigella sativa under different irrigation treatments. Ind. Crops Prod. 27, 11-16. http://dx.doi.org/10.1016/j.indcrop.2007.05.002

4. Khalid, KhA. (2006). Influence of water stress on growth, essential oil and chemical composition of herbs (Ocimum sp.). Int. Agrophys. 20(4), 289-296.

5. Ahmadian, A., Ghanbari, A., Siahsar, B., Haydari, M., Ramroodi, M. \& Mousavinik, S.M. (2011b). Study of Chamomile's yield and its components under drought stress and organic and inorganic fertilizer using and their residue. $J$. Microbiol. Antimicrob. 3(2), 23-28.

6. Farahza, K.S., Farahi, A.S. \& Sharifi, A. (2002). The effect of drought stress on yield components of Cuminum cyminum. Res. Manuf. J. 54, 42-45.

7. Ucan, K., Killi, F., Gencoglan, C. \& Merdun, H. (2007). Effect of irrigation frequency and amount on water use efficiency and yield of sesame (Sesamum indicum L.) under field conditions. Field Crops Res. 101, 249-258. http://dx.doi. org/10.1016/j.fcr.2006.11.011
8. Turner, N.C. (2004). Agronomic option for improving rainfall use efficiency of crops in dryland farming systems. $J$. Exp. Bot. 55, 2413-2525. DOI: 10.1093/jxb/erh154.

9. Khazaie, H.R., Nadjafi, F. \& Bannayan, M. (2008). Effect of irrigation frequency and planting density on herbage biomass and oil production of thyme (Thymus vulgaris) and hyssop (Hyssopus officinalis). Ind. Crops Prod. 27, 315-321. http://dx.doi.org/10.1016/j.indcrop.2007.11.007

10. Aliabadi Farahani, H., Valadabadi, A.R., Daneshian, J., Shiranirad, A.H. \& Khalvati, M.A. (2013). Medicinal and aromatic plants farming under drought conditions. Afr. J. Plant Breed. 1(5), 83-88.

11. Egilla, J.N., Davies, F.T. \& Boutton, T.W. (2005). Drought stress influences leaf water content, photosynthesis, and water use efficiency of Hibiscus rosa-sinensis at three potassium concentrations. Photosynthetica 43(1), 135-140. DOI: 10.1007/ s11099-005-5140-2.

12. Peek, M.S. \& Foreth, I.N. (2003). Microhabitat responses to resource pulses in the arid land perennial, Cryptanths flava. J. Ecol. 91, 457-466.

13. Karlidag, H., Esitken, A., Turan, M. \& Sahin, F. (2007). Effects of root inoculation of plant growth promoting rhizobacteria (PGPR) on yield, growth and nutrient element contents of leaves of apple. Sci. Hortic. 114, 16-20. http://dx.doi. org/10.1016/j.scienta.2007.04.013

14. Dong, S., Neilsen, D., Neilsen, G.H. \& Fuchigami, L.H. (2005). Foliar N application reduces soil NO3-N leaching loss in apple orchards. Plant Soil. 268, 357-366. DOI: 10.1007/ s11104-004-0333-1.

15. Vashisth, A. \& Nagarajan, S. (2010). Effect on germination and early growth characteristics in sunflower (Helianthus annuus) seeds exposed to static magnetic field. J. Plant Physiol. 167, 149-156. http://dx.doi.org/10.1016/j.jplph.2009.08.011

16. Martinez, E., Carbonell, M.V. \& Amaya, J.M. (2000). A static magnetic field of $125 \mathrm{mT}$ stimulates the initial growth stages of barley (Hordeum vulgare L.). Electro Magnetobiol. 19(3), 271-277. DOI: 10.1081/JBC-100102118.

17. Aladjadjiyan, A. (2002). Study of the influence of magnetic field on some biological characteristics of Zea mays. $J$. Cent. Eur. Agric. 3, 89-94.

18. Martinez, E., Carbonell, M.V., Amaya, J.M. \& Maqueda, R. (2009). Gemination of tomato seeds (Lycopersicon esculentum L.) under magnetic field. Int. Agrophys. 23, 45-49.

19. Katsenios, N., Efthimiadou, A., Efthimiadou, P. \& Karkanis, A. (2012). Pulsed electromagnetic fields effect in oregano rooting and vegetative propagation: A potential new organic method. Acta Agr. Scand. B-SP. 62 (1), 94-99. DOI: 10.1080/09064710.2011.570374.

20. Esitken, A. \& Turan, M. (2004). Alternating magnetic field effects on yield and plant nutrient element composition of strawberry (Fragaria x ananassa cv. Camarosa). Acta Agr. Scand. B-SP. 54, 135-139. DOI: 10.1080/09064710310019748.

21. Levin, M. \& Ernst, S.G. (1997). Applied DC magnetic fields cause alterations in the time of cell divisions and developmental abnormalities in early sea urchin embryos. Bioelectromagnetices 18, 255-263. DOI: 10.1002/(SICI)1521-186X.

22. Stange, B.C., Rowland, R.E., Rapley, B.I. \& Podd, J.V. (2002). ELF magnetic fields increase amino acid uptake into Vicia faba L. roots and alter ion movement across the plasma membrane. Bioelectromagnetics 23, 347-354. DOI: 10.1002/ bem.10026.

23. Aladjadjiyan, A. (2010). Influence of stationary magnetic field on lentil seeds. Int. Agrophys. 24, 321-324.

24. Nair, R., Varghese, S., Nair, B., Maekawa, T., Yoshida, Y. \& Sakthi Kumar, D. (2010). Nanoparticulate material delivery to plants. Plant Sci. 179(3), 154-163. http://dx.doi.org/10.1016/j. plantsci.2010.04.012

25. Joseph, T. \& Morrison, M. (2006). Nanotechnology in Agriculture and Food. A Nanoforum report. http://www. nanoforum.org. Institute of Nanotechnology. 
26. Navrotsky, A. (2000). Nanomaterials in the environment, agriculture, and technology (NEAT). J. Nanopart. Res. 2, 321-323. DOI: 10.1023/A:1010007023813.

27. Sambhy, V., MacBride, M.M. \& Peterson, B.R. (2006). Silver bromide nano particle/ polymer composites: dual action tunable antimicrobial materials. J. Am. Chem. Soc. 128, 9798-9808. DOI: 10.1021/ja061442z.

28. Choi, O., Kanjun Deng, K., Kim, N., Ross, L., Surampalli, R.Y. \& Hu, Z. (2008). The inhibitory effects of silver nanoparticles, silver ions, and silver chloride colloids on microbial growth. Water Res. 42(12), 3066-3074. http://dx.doi. org/10.1016/j.watres.2008.02.021

29. van Ieperen, W. (2007). Ion-mediated changes of xylem hydraulic resistance in plant: fact or fiction? Trends Plant Sci. 12, 137-142. http://dx.doi.org/10.1016/j.tplants.2007.03.001

30. Kumari, M., Mukherjee, A. \& Chandrasekaran, N. (2009). Genotoxicity of silver nanoparticles in Allium cepa. Sci. Total Environ. 407, 5243-5246. http://dx.doi.org/10.1016/j. scitotenv.2009.06.024

31. Stampoulis, D., Sinha, S.K. \& White, J.C. (2009). Assay-dependent phytotoxicity of nanoparticles to plants. Environ. Sci. Technol. 43, 9473-9479. DOI: 10.1021/es901695c.

32. Musante, C. \& White, J.C. (2012). Toxicity of silver and copper to Cucurbita pepo: Differential effects of nano and bulk-size particles. Environ Toxicol. 27 (9), 510-517. DOI: 10.1002/ tox. 20667.

33. Ahmadian, A., Tavassoli, A. \& Amiri, E. (2011a). The interaction effect of water stress and manure on yield components, essential oil and chemical compositions of cumin (Cuminum cyminum). Afr. J. Agric. Res. 6(10), 2309-2315. DOI: 10.5897/AJAR10.989.

34. De Souza, A., Garcia, D., Sueiro, L., Licea, L. \& Porras, E. (2005). Pre-sowing magnetic treatment of tomato seeds: effect on the growth and yield of plants cultivated late in the season. Span. J. Agric. Res. 3(1), 113-122.

35. Rochalska, M., Grabowska, K. \& Ziarnik, A. (2008). Impact of low frequency magnetic fields on yield and quality of sugar beet. Int Agrophys. 23, 163-174.

36. Dhawi, F., Al-Khayri, J.M. \& Hassan, E. (2009). Static magnetic field influence on elements composition in Date Palm (Phoenix dactylifera L.). Res. J. Agric. Biol. Sci. 5, 161-166. http://www.insinet.net/rjabs/2009/161-166.pdf

37. Hänsch, M. \& Emmerling, C. (2010). Effect of silver nanoparticels on the microbiota and enzyme activity in soil. J. Plant Nut. Soil Sci. 173(4), 554-558. DOI: 10.1002/jpln.200900358.

38. Faqenabi, F., Tajbakhsh, M., Bernooshi, I., Saber-Rezaii, M., Tahri, F., Parvizi, S., Izadkhah, M., Hasanzadeh Gorttapeh, A. \& Sedqi, H. (2009). The effect of magnetic field on growth, development and yield of safflower and its comparison with other treatments. Res. J. Biol. Sci. 4 (2), 174-178. DOI: rjbsci.2009.174.178.

39. Earl, H. \& Davis, R.F. (2003). Effect of drought stress on leaf and whole canopy radiation use efficiency and yield of maize. Agron. J. 95 (3), 688-696. DOI: 10.2134/agronj2003.6880.

40. Motamedi-Mirhosseini, L., Mohammadi-Nejad, G., Golkar, P. \& Bahrami-Nejad, A. (2011). Evaluation of some drought resistance criteria in Cumin (Cuminum cyminum L.) landraces. Adv. Environ. Biol. 5(8), 2369-2372.

41. Cheruth, A.J., Gopi, R., Sankar, B., Gomathinayagam, M. \& Panneerselvam, R. (2008). Differential responses in water use efficiency in two varieties of Catharanthus roseus under drought stress. C.R. Biol. 331(1), 42-47. http://dx.doi. org/10.1016/j.crvi.2007.11.003

42. Faraji, A., Latifi, N., Soltani, A. \& Shirani Rad, A.H. (2009). Seed yield and water use efficiency of canola (Brassica napus L.) as affected by high temperature stress and supplemental irrigation. Agric. Water Manage. 96, 132-140. http:// dx.doi.org/10.1016/j.agwat.2008.07.014 